\title{
Morphological and molecular identification of the potato cyst nematodes Globodera rostochiensis and G. pallida in Portuguese potato fields
}

\author{
Maria J. CAMACHO ${ }^{1,2}$, Filomena NóBREGA ${ }^{2}$, Arlindo LimA ${ }^{1}$, Manuel MotA ${ }^{3,4}$ and \\ Maria L. INÁCIO ${ }^{2, *}$ \\ ${ }^{1}$ Instituto Superior de Agronomia da Universidade de Lisboa, Tapada da Ajuda, 1349-017 Lisboa, Portugal \\ ${ }^{2}$ Instituto Nacional de Investigação Agraria e Veterinária (INIAV, I.P.), Quinta do Marquês, 2780-159 Oeiras, Portugal \\ ${ }^{3}$ NemaLab/ICAAM, Instituto de Ciências Agrárias e Ambientais Mediterrânicas \& Dept. de Biologia, Universidade de \\ Évora, Núcleo da Mitra, Ap. 94, 7002-554 Évora, Portugal \\ ${ }^{4}$ Dept. Ciências da Vida, Universidade Lusófona de Humanidades e Tecnologias, EPCV, C. Grande 376, 1749-024 \\ Lisboa, Portugal
}

Received: 23 March 2017; revised: 19 July 2017 Accepted for publication: 20 July 2017; available online: ???

\begin{abstract}
Summary - The potato cyst nematodes (PCN) Globodera rostochiensis and G. pallida pose one of the greatest threats to potato crops worldwide and are subject to strict quarantine regulations in many countries. The identification of these Globodera species based on morphology may be ambiguous due to the variability of the main morphological features and the overlapping of the standard parameters in these two species; thus, confirmation via molecular methods is recommended. Multiplex PCR with speciesspecific primers (ITS5/PITSp4 + PITSr3) allows both species to be distinguished. However, despite the development of molecular identification methods, the morphological approach remains useful as a complementary diagnostic technique. In this work, we report results of morphological and molecular analyses that were carried out in two Globodera species from Portuguese potato fields. The average morphometric values of 40 cysts and 40 second-stage juveniles were generally within the expected ranges for G. pallida and G. rostochiensis with some variations noted. Molecular analysis with multiplex PCR confirmed the morphometric identification. The present results confirmed the occurrence of two potato cyst nematode species, G. rostochiensis and G. pallida. Surprisingly, the analysis of soils from Portuguese potato fields detected a greater number of samples infested with G. pallida, which is contrary to expectation as G. rostochiensis has been considered the most widespread species in Portugal. The distinction between the two species is therefore essential in order to detect their presence in the country with a view to re-evaluating the control measures implemented so far and adopting more effective practices.
\end{abstract}

Keywords - Heteroderidae, morphology, multiplex PCR, Solanum tuberosum.

Cyst nematodes (Heterodera and Globodera) are an economically important group of plant-parasitic nematodes, present throughout the world, affecting all major horticultural crops (Marks \& Brodie, 1998). In particular, potato cyst nematodes (PCN) can be devastating to potato fields if they are not controlled in a timely manner, leading to the abandonment of vast areas of production (Van de Vossenberg et al., 2014).

Species of PCN include the golden potato cyst nematode, Globodera rostochiensis (Wollenweber, 1923) Skarbilovich, 1959, and the pale potato cyst nematode, G. pal- lida Stone, 1973, and are considered harmful quarantine organisms, described in European Union Directives 2000/29/EC and 2009/7/EC and are also part of EPPO A2 List (quarantine species already present in the EPPO region, A2/125 and A2/124, respectively) (EPPO, 2015). These species are regulated by the European Directive 2007/33/EC on the control of potato cyst nematodes and are subject to stringent regulatory measures when detected singly or in combination (EPPO, 2013, 2015).

Globodera rostochiensis and G. pallida, originating from the Andes in southern Peru, have spread worldwide

*Corresponding author, e-mail: lurdes.inacio@iniav.pt 
(Grenier et al., 2010). They are thought to have been introduced into Europe in the 16-17th century with potato tubers that would have carried infested soil. In Portugal, G. rostochiensis was first reported in 1956 in a field of seed potatoes near Bragança (Trás-os-Montes district) (Macara, 1963) and is currently present in all potatoproducing regions of the country (Cunha et al., 2004; DGAV, 2015). Globodera pallida was first identified in the country in 1988, also in Trás-os-Montes (Santos \& Fernandes, 1988).

In Portugal, the potato has a great social and economic importance, since it is grown throughout the country, including on the islands of Madeira and Açores. The most representative production areas are Bragança, Chaves, Aveiro, Viseu, Oeste Region and Montijo. As potato cyst nematodes pose a risk to potato production in Portugal, a national potato nematode survey was implemented in 2010, establishing a new framework for phytosanitary protection measures for these harmful organisms, with a view to avoid dispersion in national and community territories and to ensure potato production of a guaranteed quality for consumers.

Due to their huge economic and trade impacts, it is crucial to distinguish these species accurately using diagnostic tools. Morphological identification, based on a few characters of the second-stage juvenile (J2) and of the perineal area of the cyst, has been quite successful but always carries some uncertainty (Bačić et al., 2013; Seesao et al., 2016; Tirchi et al., 2016). Therefore, due to the variability of the main morphological features and the overlapping of standard diagnostic parameters in these two species, a confirmation through molecular methods is recommended. Molecular methods such as multiplex PCR with species-specific primers (ITS5/PITSp4 + PITSr3) (Bulman \& Marshall, 1997) have been successfully applied to differentiate $G$. rostochiensis from $G$. pallida.

The aim of this study was to identify $G$. rostochiensis is and G. pallida from Portuguese potato fields using morphological and PCR-based methods. The rapid identification of the two species is essential to detect their presence in the nation in order to re-evaluate the control measures implemented so far and adopt more effective practices.

\section{Materials and methods}

Nematode sample reference material (cysts of $G$. pallida $\mathrm{Pa} 3$ (E400) and G. rostochiensis Ro 2/3) was provided by NVWA - the Netherlands Food and Consumer Product Safety Authority, Wageningen, The Netherlands.
The Portuguese biological material was extracted from samples of infested soils collected from the main producing potato regions in 2015 and 2016 in the northern (Viana do Castelo, Chaves and Esposende), central (Vagos, Mira and Cantanhede) and southern cultivation areas (Salvaterra de Magos). Those samples were provided by the Laboratory of Nematology of INIAV - the National Institute for Agrarian and Veterinary Research, Oeiras, Portugal. Cysts were extracted from the soil samples using the Fenwick can method (Fenwick, 1940) and the J2 were recovered from cysts. Eight isolates of Globodera spp. from 2015 and 32 isolates of Globodera spp. from 2016 were used for morphological and molecular analysis.

\section{MORPHOLOGICAL CHARACTERISATION}

Vulval cones were cut from cysts with an ophthalmic scalpel and mounted in sterilised tap water. Juveniles were heat-killed and examined using an Olympus BX41 bright field light microscope. Pictures were taken with an Olympus DP10 digital camera. The observed characters of cysts and $\mathrm{J} 2$ were compared with those from the reference materials and descriptions in the literature (Marks \& Brodie, 1998; EPPO, 2013). Measurements were made using a ProgResSpeed XT core 5 - Jenoptik image software and dimensions are expressed in $\mu \mathrm{m}$. Morphological identification of PCN was based on a combination of $\mathrm{J} 2$ and cyst characters: body length, stylet length, tail and hyaline region, fenestra diam., distance fenestra to anus, Granek's ratio (the distance from anus to the nearest edge of vulval basin divided by vulval basin diam.), and number of cuticular ridges between vulva and anus.

\section{NemATOdE DNA}

Half cysts containing eggs and J2 (originating from cysts used for the previous morphological characterisation) were used for DNA extraction. Each half cyst was transferred to an Eppendorf tube with $10 \mu \mathrm{l}$ of distilled sterilised water, frozen in liquid nitrogen and homogenised with a micropestle (Eppendorf). The homogenate was incubated overnight at $56^{\circ} \mathrm{C}$ in lysis buffer (ATL) and $100 \mu \mathrm{g} \mathrm{ml}^{-1}$ proteinase $\mathrm{K}$. After incubation, total genomic DNA extraction was performed using the DNeasy Blood \& Tissue Kit (Qiagen), following the manufacturer's instructions. DNA samples were stored at $-20^{\circ} \mathrm{C}$. 


\section{MULTIPLEX PCR BY SPECIES-SPECIFIC PRIMERS}

The internal transcribed spacer region (ITS) of the ribosomal DNA repeat unit was amplified by multiplex PCR. Multiplex PCR reactions were performed in a $25 \mu \mathrm{l}$ final volume of using the Promega GoTaq Flexi DNA Polymerase Kit (Promega), containing $1 \mu$ l template DNA, $5 \mu \mathrm{l}$ GoTaq Flexi PCR buffer, $1.5 \mathrm{mM} \mathrm{MgCl}$, $0.20 \mathrm{mM}$ each dNTPs, $1.25 \mathrm{U}$ GoTaq Flexi DNA Polymerase (Promega) and $0.4 \mu \mathrm{M}$ of each primer in a Biometra TGradient thermocycler (Biometra). The set of primers for G. rostochiensis were: ITS5 (5'-GGA AGT AAA AGT CGT AAC AAG G-3') and PITSr3 (5'-AGC GCA GAC ATG CCG CAA-3') and for $G$. pallida: ITS5 (5'-GGA AGT AAA AGT CGT AAC AAG G-3') and PITSp4 (5'ACA ACA GCA ATC GTC GAG-3') (Bulman \& Marshall, 1997).

The amplification profile for ITS-rRNA consisted of an initial denaturation of $94^{\circ} \mathrm{C}$ for 2 min followed by 35 cycles of $94^{\circ} \mathrm{C}$ for $30 \mathrm{~s}, 55^{\circ} \mathrm{C}$ for $30 \mathrm{~s}$ and $72^{\circ} \mathrm{C}$ for $30 \mathrm{~s}$ and a final extension of $72^{\circ} \mathrm{C}$ for $7 \mathrm{~min}$ (EPPO, 2013). The amplified products were loaded onto a $1.5 \%$ agarose gel containing $0.5 \mu \mathrm{g} \cdot \mathrm{ml}^{-1}$ ethidium bromide and $0.5 \times$ Trisborate-EDTA (TBE) running buffer and electrophoresed at $5 \mathrm{~V} / \mathrm{cm}$. Amplifications were visualised using the VersaDoc Gel Imaging System (Bio-Rad). The expected length of the PCR products was $265 \mathrm{bp}$ for G. pallida and 434 bp for G. rostochiensis. Possible contamination was checked by including negative controls (no DNA) in all amplifications.

Amplification PCR products using the same pair of primers were used for one previously confirmed G. rostochiensis isolate (Ro 2/3) and one isolate of G. pallida (Pa3 (E400)) from NVWA used as positive controls.

\section{Results}

\section{MORPHOLOGY AND MORPHOMETRICS}

The morphological characters of the 40 cysts and 40 J2 from Portuguese populations did not always match the descriptions of G. rostochiensis and G. pallida (Table 1), but the morphometric average values were within the range described in the literature (Marks \& Brodie, 1998; EPPO, 2013) (Table 2).

\section{SECOND-STAGE JUVENILES}

The $\mathrm{J} 2$ of both species follow the general description of these species: a vermiform body, tapering at both extremities, more so posteriorly. The tail reduced, shorter in G. rostochiensis. In both species the head is rounded, slightly offset with prominent cephalic sclerotisation. The stylet is well developed with anteriorly flattened to rounded knobs in $G$. rostochiensis and with distinct forwardly projecting knobs in G. pallida. However, in some situations, the characterisation of the knob shape may be ambiguous.

\section{CYSTS}

Cysts were yellow or brown in colour, spherical in shape, with protruding necks and lacking a terminal cone. Vulva fenestrate, anus prominent and visible in almost all specimens, with a V-shaped mark. However, the cyst wall pattern did not always permit species identification.

\section{PCR SPECIES-SPECIFIC PRIMERS}

All DNA extracts from Portuguese samples produced amplification products of the same size as those obtained from the G. rostochiensis and G. pallida controls when species-specific primers were used in multiplex PCR reactions.

Nine of the Portuguese samples yielded a single amplification product of $c a 434 \mathrm{bp}$, the same size as the one from the known $G$. rostochiensis control and 31 of the Portuguese samples yielded a single PCR product of $c a$ $265 \mathrm{bp}$, the same size as that from the known G. pallida control (Fig. 1).

From the molecular data obtained in this study, two potato cyst nematode species (G. rostochiensis and G. pallida) were identified (Table 3 ), and the analysis of soils coming from Portuguese potato fields detected a greater number of samples infested with G. pallida, which contradicted expectations as $G$. rostochiensis has been considered the most widespread species in Portugal (Conceição et al., 2003; Cunha et al., 2004).

\section{Discussion}

The results in this study clearly demonstrate that the Globodera populations present in Portuguese potato fields are morphologically variable, with some features outside the ranges expected for G. pallida or G. rostochiensis, making it difficult to identify PCN species when cysts and $\mathrm{J} 2$ are individually analysed. However, morphometric average values (Table 2) were within the range provided in the literature (Marks \& Brodie, 1998; EPPO, 2013). 
Table 1. Morphometric characteristics of Globodera rostochiensis and G. pallida cysts and second-stage juveniles of Portuguese ( $\mathrm{n}=$ 24 from the northern, $\mathrm{n}=15$ from the central and $\mathrm{n}=1$ from the southern cultivation area; total of $\mathrm{n}=40$ samples) and reference PCN species. All measurements (absolute values) are in $\mu \mathrm{m}$.

\begin{tabular}{|c|c|c|c|c|c|c|c|c|}
\hline \multirow[t]{2}{*}{ Cyst No. } & \multicolumn{4}{|c|}{ Second-stage juvenile } & \multicolumn{4}{|c|}{ Cyst } \\
\hline & $\begin{array}{l}\text { Body } \\
\text { length }\end{array}$ & $\begin{array}{c}\text { Tail } \\
\text { length }\end{array}$ & $\begin{array}{c}\text { Hyaline } \\
\text { region }\end{array}$ & $\begin{array}{l}\text { Stylet } \\
\text { length }\end{array}$ & $\begin{array}{c}\text { Fenestra } \\
\text { to anus }\end{array}$ & $\begin{array}{c}\text { Fenestra } \\
\text { diam. }\end{array}$ & $\begin{array}{l}\text { Granek's } \\
\text { ratio }\end{array}$ & $\begin{array}{c}\text { No. cuticular } \\
\text { ridges }\end{array}$ \\
\hline \multicolumn{9}{|c|}{ Portuguese samples } \\
\hline 1 & 385.0 & $(*)$ & 26.4 & 28.9 & 42.6 & 21.5 & 2.0 & $(*)$ \\
\hline 2 & 499.0 & 29.5 & 19.5 & 20.8 & 34.7 & 19.1 & 1.8 & 13 \\
\hline 3 & 395.0 & $(*)$ & $(*)$ & $\overline{23.7}$ & 55.6 & 14.7 & 3.8 & $>14$ \\
\hline 4 & 477.9 & 52.7 & $(*)$ & 22.1 & $\overline{51.1}$ & $\overline{25.3}$ & 2.0 & $>14$ \\
\hline 5 & 481.9 & 52.1 & 26.9 & 23.9 & 76.8 & 22.3 & $\underline{3.5}$ & $>14$ \\
\hline 6 & 534.0 & 50.2 & 28.8 & 26.3 & $\overline{40.0}$ & 29.3 & $\overline{1.4}$ & 11 \\
\hline 7 & 414.7 & $(*)$ & $(*)$ & 21.4 & $\underline{92.6}$ & 22.6 & $\underline{4.1}$ & $>14$ \\
\hline 8 & $\overline{375.4}$ & 42.2 & 23.0 & $\overline{24.8}$ & $\overline{42.4}$ & 20.6 & $\overline{2.1}$ & 12 \\
\hline 9 & $\overline{406.1}$ & $\overline{49.3}$ & 23.4 & 28.7 & 109.1 & 36.1 & 3.0 & $>14$ \\
\hline 10 & $\overline{399.6}$ & $\overline{42.4}$ & 17.5 & 27.4 & 52.0 & 23.5 & 2.2 & 14 \\
\hline 11 & $\overline{379.0}$ & $\overline{48.8}$ & 19.7 & 28.1 & 59.9 & 19.2 & $\underline{3.1}$ & $>14$ \\
\hline 12 & $\overline{422.2}$ & $\overline{43.8}$ & 28.6 & 27.1 & 51.9 & 23.8 & $\overline{2.2}$ & $(*)$ \\
\hline 13 & $\overline{404.1}$ & $\overline{44.2}$ & 22.5 & 21.4 & 152.3 & 31.8 & 4.8 & $(*)$ \\
\hline 14 & $(*)$ & $\overline{46.3}$ & 28.2 & 21.4 & 93.4 & 24.1 & $\overline{3.9}$ & $>14$ \\
\hline 15 & 444.9 & $\overline{50.9}$ & 28.0 & 25.0 & 58.6 & 24.8 & $\overline{2.4}$ & 15 \\
\hline 16 & $\overline{405.0}$ & 50.3 & 25.7 & 25.2 & 30.6 & 18.8 & 1.6 & $(*)$ \\
\hline 17 & $\overline{405.9}$ & 48.5 & 27.7 & 22.1 & 87.6 & 30.2 & 2.9 & $(*)$ \\
\hline 18 & $\overline{390.0}$ & $\overline{(*)}$ & 18.6 & 21.5 & 71.1 & 18.8 & 3.8 & $>14$ \\
\hline 19 & $\overline{416.6}$ & 50.1 & $\overline{26.3}$ & $\overline{25.5}$ & $\overline{44.4}$ & 22.2 & $\overline{2.0}$ & 10 \\
\hline 20 & $\overline{433.7}$ & 49.3 & 26.7 & 25.0 & 46.7 & 22.2 & 2.1 & $(*)$ \\
\hline 21 & $\overline{401.4}$ & $\overline{50.1}$ & 26.3 & 23.2 & 92.7 & 24.0 & 3.9 & $>14$ \\
\hline 22 & $\overline{476.8}$ & 51.6 & 28.6 & 24.5 & $\overline{63.7}$ & $\underline{13.3}$ & $\overline{4.8}$ & 12 \\
\hline 23 & 511.2 & 51.3 & 23.7 & 26.4 & $\overline{32.9}$ & $\overline{10.6}$ & $\overline{3.1}$ & 14 \\
\hline 24 & 436.9 & $\underline{46.0}$ & $\overline{28.3}$ & 22.2 & $\underline{58.1}$ & $\underline{17.6}$ & $\overline{3.3}$ & 17 \\
\hline 25 & 437.9 & 46.9 & 19.1 & 23.8 & 61.7 & $\overline{22.4}$ & 2.8 & 20 \\
\hline 26 & $\overline{405.7}$ & $\overline{46.5}$ & $\overline{21.5}$ & 24.5 & $\overline{30.1}$ & $\underline{13.0}$ & 2.3 & $\overline{7}$ \\
\hline 27 & $\overline{487.3}$ & $\overline{45.3}$ & $\overline{32.2}$ & 22.8 & 55.7 & $\overline{16.7}$ & 3.3 & $>14$ \\
\hline 28 & $\overline{458.7}$ & $\overline{(*)}$ & 43.5 & 20.7 & $\overline{48.3}$ & $\overline{23.6}$ & $\overline{2.0}$ & 12 \\
\hline 29 & 381.9 & 42.5 & 22.8 & $\overline{23.8}$ & 45.7 & 19.4 & 2.4 & $>14$ \\
\hline 30 & $\overline{483.0}$ & $\overline{47.8}$ & $\overline{29.4}$ & 22.2 & 21.2 & 19.6 & 1.1 & 10 \\
\hline 31 & 477.1 & $\overline{49.4}$ & 25.6 & 22.7 & 65.3 & 28.8 & 2.3 & 16 \\
\hline 32 & 393.3 & 45.6 & $\overline{19.3}$ & 22.0 & $\overline{93.0}$ & 26.1 & 3.6 & $>14$ \\
\hline 33 & $\overline{386.7}$ & $\overline{34.6}$ & $\overline{19.2}$ & 21.9 & $\overline{47.2}$ & 16.3 & $\overline{2.9}$ & 12 \\
\hline 34 & $\overline{425.9}$ & 49.6 & 25.9 & 25.6 & 42.0 & 24.5 & 1.7 & 8 \\
\hline 35 & $\overline{390.8}$ & $\overline{41.5}$ & 19.9 & 24.8 & 32.0 & 27.3 & 1.2 & 9 \\
\hline 36 & $\overline{375.8}$ & 31.7 & 17.3 & 25.3 & 63.0 & 18.8 & 3.4 & 16 \\
\hline 37 & $\overline{420.9}$ & $\overline{44.4}$ & $\overline{21.8}$ & 22.2 & $\overline{66.6}$ & 17.9 & $\overline{3.7}$ & $(*)$ \\
\hline 38 & 463.3 & 46.0 & 31.2 & 23.1 & 52.6 & 26.9 & 2.0 & $(*)$ \\
\hline 39 & 446.9 & $\overline{50.3}$ & 23.9 & 22.1 & 54.7 & 21.0 & 2.6 & $(*)$ \\
\hline 40 & 380.2 & 42.5 & 22.8 & 23.2 & 36.8 & 19.0 & 1.9 & 10 \\
\hline
\end{tabular}


Table 1. (Continued.)

\begin{tabular}{|c|c|c|c|c|c|c|c|c|}
\hline \multirow[t]{2}{*}{ Cyst No. } & \multicolumn{4}{|c|}{ Second-stage juvenile } & \multicolumn{4}{|c|}{ Cyst } \\
\hline & $\begin{array}{l}\text { Body } \\
\text { length }\end{array}$ & $\begin{array}{c}\text { Tail } \\
\text { length }\end{array}$ & $\begin{array}{l}\text { Hyaline } \\
\text { region }\end{array}$ & $\begin{array}{l}\text { Stylet } \\
\text { length }\end{array}$ & $\begin{array}{l}\text { Fenestra } \\
\text { to anus }\end{array}$ & $\begin{array}{c}\text { Fenestra } \\
\text { diam. }\end{array}$ & $\begin{array}{l}\text { Granek's } \\
\text { ratio }\end{array}$ & $\begin{array}{c}\text { No. cuticular } \\
\text { ridges }\end{array}$ \\
\hline \multicolumn{9}{|l|}{ Reference samples } \\
\hline P3 & $(*)$ & 50.7 & $\underline{17.0}$ & $\underline{21.2}$ & $\underline{63.7}$ & 20.3 & $\underline{3.1}$ & 14 \\
\hline $\mathrm{P} 4$ & $(*)$ & 76.0 & $\overline{34.3}$ & $\overline{25.8}$ & $\overline{52.0}$ & 35.0 & $\overline{1.5}$ & 11 \\
\hline P5 & $(*)$ & 61.4 & 28.0 & 25.1 & 52.2 & 30.4 & 1.7 & $(*)$ \\
\hline P6 & $(*)$ & 48.4 & 23.6 & 25.8 & 47.0 & 21.7 & 2.2 & 9 \\
\hline $\mathrm{R} 4$ & 396.20 & 65.3 & 29.1 & 23.5 & 49.6 & 31.8 & 1.6 & $(*)$ \\
\hline R5 & $(*)$ & 52.5 & 30.4 & 23.4 & 31.3 & 21.0 & 1.5 & $(*)$ \\
\hline $\mathrm{R} 11$ & $(*)$ & $\underline{48.0}$ & $\underline{20.3}$ & 22.6 & $\underline{59.7}$ & 18.2 & $\underline{3.3}$ & $(*)$ \\
\hline $\mathrm{R} 12$ & $\underline{441.90}$ & $\underline{47.2}$ & $\overline{25.5}$ & 22.2 & $\underline{76.6}$ & 33.7 & $\overline{2.3}$ & $(*)$ \\
\hline \multicolumn{9}{|c|}{ Reference measurements } \\
\hline Marks \& Brodie & $(*)$ & $(*)$ & $(*)$ & $21-23(22)$ & $37-77(>55)$ & $8-20(<19)$ & $1.3-9.5(>3)$ & $12-31(>14)$ \\
\hline (1998) & $\overline{(*)}$ & $\overline{(*)}$ & $\overline{(*)}$ & $2 \overline{1-26(>23)}$ & $\overline{22-67(<50)}$ & $\overline{18-21(>19)}$ & $\overline{1.2-3.5(<3)}$ & $\overline{8-20(<14)}$ \\
\hline PM 7_70 (3) & $452-486$ & $50-53$ & $26-27$ & $23-24$ & $48-54$ & $(*)$ & $2.1-2.5$ & 12 \\
\hline PM 7_70 (3) & $\underline{392-468}$ & 44-51 & $\underline{20-27}$ & $\underline{20-22}$ & $\underline{51-70}$ & $(*)$ & 3.0-4.5 & $\underline{17-20}$ \\
\hline PM 7_70 (3) & $452-468$ & $\overline{50-51}$ & $26-27$ & $22-23$ & $\overline{51-54}$ & $1 \overline{8-20}$ & $\overline{2.5-3.0}$ & $\overline{12-17}$ \\
\hline
\end{tabular}

(*): no data; italics: G. pallida data; underlined: G. rostochiensis data; roman: both species characteristics.

Table 2. Morphometric characteristics of cysts and second-stage juveniles of Portuguese (Pt) compared to reference (Ref) Globodera pallida and G. rostochiensis. All measurements are in $\mu \mathrm{m}$ and in the form: mean \pm s.d. (range).

\begin{tabular}{|c|c|c|c|c|}
\hline & $\begin{array}{l}\text { G. pallida }(\mathrm{Pt}) \\
(\mathrm{n}=31)\end{array}$ & $\begin{array}{l}\text { G. rostochiensis }(\mathrm{Pt}) \\
(\mathrm{n}=9)\end{array}$ & $\begin{array}{c}\text { G. pallida }(\mathrm{Ref}) \\
(\mathrm{n}=4)\end{array}$ & $\begin{array}{l}\text { G. rostochiensis (Ref) } \\
(\mathrm{n}=4)\end{array}$ \\
\hline \multicolumn{5}{|l|}{ Second-stage juvenile } \\
\hline $\mathrm{L}$ & $\begin{array}{c}428 \pm 42.8 \\
(375-534)\end{array}$ & $\begin{array}{c}429 \pm 43.9 \\
(380-499)\end{array}$ & $(*)$ & $\begin{array}{c}419 \pm 32.3 \\
(396-442)\end{array}$ \\
\hline Stylet length & $\begin{array}{l}24.4 \pm 2.3 \\
(20.7-28.9)\end{array}$ & $\begin{array}{l}22.4 \pm 0.9 \\
(20.8-23.7)\end{array}$ & $\begin{array}{l}24.5 \pm 2.2 \\
(21.2-25.8)\end{array}$ & $\begin{array}{l}23.0 \pm 0.8 \\
(22.2-23.5)\end{array}$ \\
\hline Tail length & $\begin{array}{l}47.1 \pm 4.5 \\
(31.7-52.7)\end{array}$ & $\begin{array}{l}44.7 \pm 5.2 \\
(34.6-50.3)\end{array}$ & $\begin{array}{l}52.8 \pm 5.9 \\
(48.4-61.4)\end{array}$ & $\begin{array}{l}49.9 \pm 2.6 \\
(47.2-52.5)\end{array}$ \\
\hline Hyaline region & $\begin{array}{l}25.4 \pm 5.3 \\
(17.3-43.5)\end{array}$ & $\begin{array}{l}22.9 \pm 4.1 \\
(19.2-31.2)\end{array}$ & $\begin{array}{l}24.4 \pm 2.4 \\
(22.9-28.0)\end{array}$ & $\begin{array}{l}26.2 \pm 4.3 \\
(20.3-29.8)\end{array}$ \\
\hline \multicolumn{5}{|l|}{ Cyst } \\
\hline Fenestra diam. & $\begin{array}{l}22.2 \pm 5.4 \\
(10.6-36.1)\end{array}$ & $\begin{array}{l}21.1 \pm 5.0 \\
(14.7-28.8)\end{array}$ & $\begin{array}{l}23.9 \pm 4.5 \\
(20.3-30.4)\end{array}$ & $\begin{array}{l}21.0 \pm 2.2 \\
(18.2-23.7)\end{array}$ \\
\hline Fenestra to anus & $\begin{array}{l}59.7 \pm 27.4 \\
(21.2-152.3)\end{array}$ & $\begin{array}{c}56.3 \pm 17.6 \\
(34.7-93.0)\end{array}$ & $\begin{array}{l}53.7 \pm 7.1 \\
(47.0-63.7)\end{array}$ & $\begin{array}{c}54.3 \pm 18.9 \\
(31.3-76.6)\end{array}$ \\
\hline Granek's ratio & $\begin{array}{l}2.8 \pm 1.1 \\
(1.1-5.1)\end{array}$ & $\begin{array}{l}2.8 \pm 0.8 \\
(2.0-3.8)\end{array}$ & $\begin{array}{l}2.1 \pm 0.7 \\
(1.5-3.1)\end{array}$ & $\begin{array}{l}2.2 \pm 0.8 \\
(1.5-3.3)\end{array}$ \\
\hline No. cuticular ridges & $\begin{array}{c}12.5 \pm 3.6 \\
(7-20)\end{array}$ & $\begin{array}{c}12.8 \pm 2.5 \\
(10-16)\end{array}$ & $\begin{array}{l}11.3 \pm 2.5 \\
(9-14)\end{array}$ & $>14$ \\
\hline
\end{tabular}

(*): no data. 


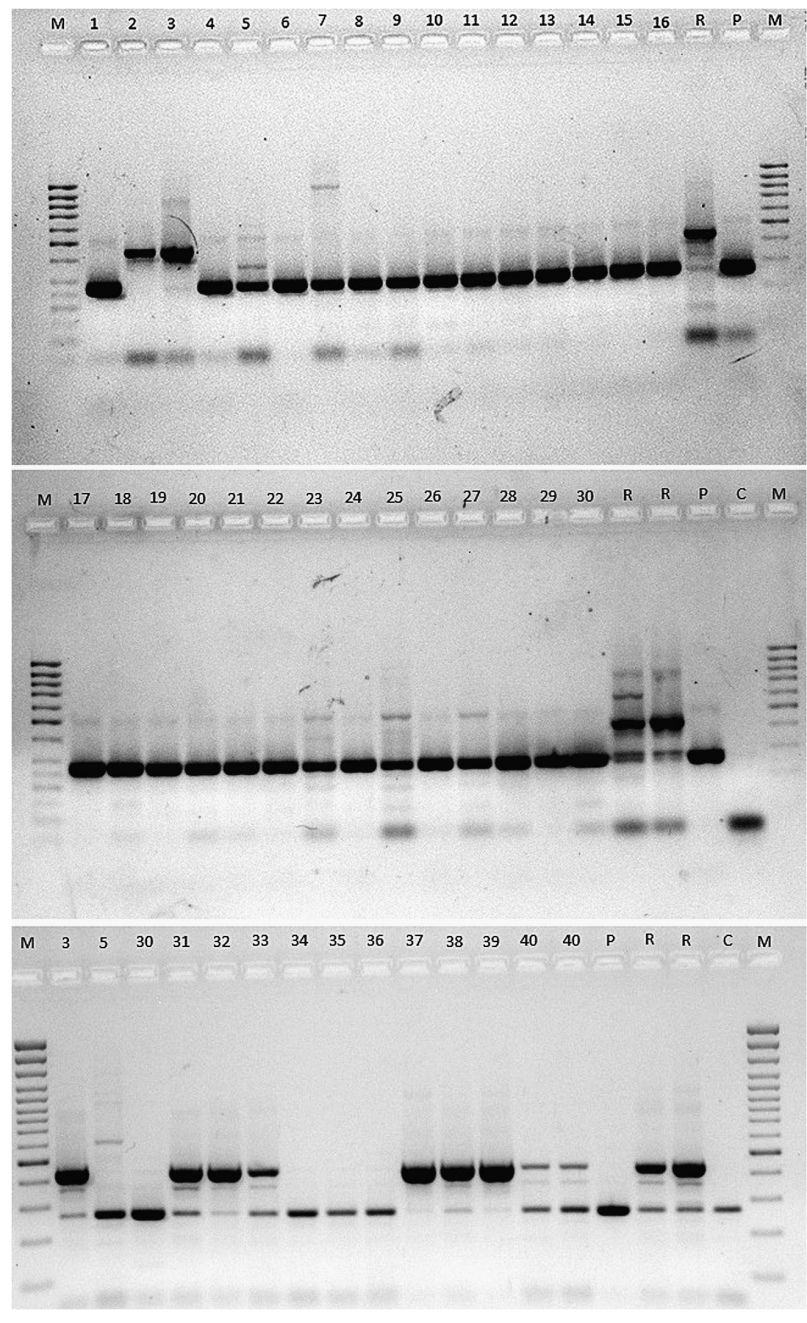

Fig. 1. Molecular identification of Portuguese PCN. Agarose gel $(1.5 \%)$ of the amplified products obtained with multiplex polymerase chain reaction using primers PITSr3, PITSp4 and the common primer ITS5 $\mathrm{M}=$ GeneRuler $100 \mathrm{bp}$ DNA Ladder (Thermo Scientific); 1-40 = Portuguese Globodera spp.; R = reference Globodera rostochiensis; $\mathrm{P}=$ reference $G$. pallida; $\mathrm{C}=\mathrm{PCR}$ control.

According to the obtained morphometric data, morphological characterisation did not always match the molecular identification (as shown by comparing the morphological characteristics typical of $G$. rostochiensis species of samples nos 7, 11, 13, 18, 24, 27 and 36 in Table 1 and their molecular identification as G. pallida in Table 3. On the other hand, sample no. 38 presented morphological characteristics of G. pallida yet was molecularly identified as G. rostochiensis). These species may be variable at morphological level, so it is recommended that sequence-
Table 3. Identification of Globodera species extracted from soil samples.

\begin{tabular}{|c|c|c|}
\hline Cyst No. & Soil sample & Multiplex PCR identification \\
\hline 1 & Gb1_2016 & G. pallida \\
\hline 2 & Gb10_2015 & G. rostochiensis \\
\hline \multicolumn{3}{|l|}{3} \\
\hline 4 & Gb17_2015 & G. pallida \\
\hline \multicolumn{3}{|l|}{5} \\
\hline \multicolumn{3}{|l|}{6} \\
\hline \multicolumn{3}{|l|}{7} \\
\hline \multicolumn{3}{|l|}{8} \\
\hline 9 & Gb2_2016 & G. pallida \\
\hline \multicolumn{3}{|l|}{10} \\
\hline \multicolumn{3}{|l|}{11} \\
\hline \multicolumn{3}{|l|}{12} \\
\hline \multicolumn{3}{|l|}{13} \\
\hline 14 & Gb3_2016 & G. pallida \\
\hline \multicolumn{3}{|l|}{15} \\
\hline \multicolumn{3}{|l|}{16} \\
\hline \multicolumn{3}{|l|}{17} \\
\hline \multicolumn{3}{|l|}{18} \\
\hline \multicolumn{3}{|l|}{19} \\
\hline \multicolumn{3}{|l|}{20} \\
\hline \multicolumn{3}{|l|}{21} \\
\hline \multicolumn{3}{|l|}{22} \\
\hline \multicolumn{3}{|l|}{23} \\
\hline \multicolumn{3}{|l|}{24} \\
\hline \multicolumn{3}{|l|}{25} \\
\hline \multicolumn{3}{|l|}{26} \\
\hline \multicolumn{3}{|l|}{27} \\
\hline \multicolumn{3}{|l|}{28} \\
\hline \multicolumn{3}{|l|}{29} \\
\hline \multicolumn{3}{|l|}{30} \\
\hline 31 & Gb4_2016 & G. rostochiensis \\
\hline \multicolumn{3}{|l|}{32} \\
\hline \multicolumn{3}{|l|}{33} \\
\hline 34 & Gb5_2016 & G. pallida \\
\hline 35 & & \\
\hline 36 & & \\
\hline 37 & Gb6_2016 & G. rostochiensis \\
\hline 38 & & \\
\hline 39 & & \\
\hline 40 & Gb4_2016 & G. rostochiensis \\
\hline
\end{tabular}

specific multiplex PCR (Bulman \& Marshall, 1997) is used to complement the morphological diagnosis of the Portuguese populations.

Also, the analysis of soils from the national potato fields in 2015 and 2016 revealed a greater number of samples infested with $G$. pallida. Five of the nine soil samples analysed were infested with this species, showing 
a trend towards an increase of G. pallida in Portugal. In addition, it was verified that all the main areas of potato cultivation are already infested with G. pallida. This may have resulted from the application of control measures for potato cyst nematodes through the intensive use of G. rostochiensis-resistant cultivars, as occurred in the UK (Varypatakis et al., 2016). It is crucial to distinguish these species by phytosanitary diagnostic tools since resistant potato cultivars for G. pallida are less available, whilst the occurrence of $G$. rostochiensis does not impact potato cultures significantly as most of the potato cultivars used nowadays are resistant or tolerant to this species (Douda et al., 2014).

In this context, the National Survey Plan for PCN should cover the largest potato production area possible, with particular attention to the seed potato fields for the exclusion of both species. If feasible, this survey should also be intensified in order to confirm the dispersion trend of G. pallida with a view to re-evaluate the control measures so far implemented and for the adoption of more effective practices.

\section{References}

Bačić, J., Gerič Stare, B., Širca, S. \& Urek, G. (2013). [Morphometric and molecular analysis of potato cyst nematodes from Serbia.] Zbornik Predavanj in Referatov 11, 369-372.

Bulman, S. \& Marshall, J. (1997). Differentiation of Australasian potato cyst nematode $(\mathrm{PCN})$ populations using the polymerase chain reaction (PCR). New Zealand Journal of Crop and Horticultural Science 25, 123-129. DOI: 10.1080/ 01140671.1997 .9513998

Conceição, I., Santos, M., Abrantes, I. \& Santos, S. (2003). Using RAPD markers to analyse genetic diversity in Portuguese potato cyst nematode populations. Nematology 5, 137-143. DOI: $10.1163 / 156854102765216759$

Cunha, M., Conceição, I., Abrantes, I., Evans, K. \& Santos, S. (2004). Characterisation of potato cyst nematode populations from Portugal. Nematology 6, 55-58. DOI: 10.1163/ 156854104323072928

DGAV (2015). Organismos de quarentena. Acções realizadas. Relatórios de 2014. Lisbon, Portugal, Direção-Geral de Alimentação e Veterinária.

Douda, O., Zouhar, M., Renco, M. \& Marek, M. (2014). Molecular and morphological exploration of a mixed population of two potato-parasitizing nematode species, Globodera rostochiensis and G. pallida. Helminthologia 51, 3-6. DOI: 10. 2478/s11687-014-0201-3

EPPO (2013). Globodera rostochiensis and Globodera pallida PM 7/40 (3). European and Mediterranean Plant Protection Organization. EPPO Bulletin 39, 354-368. DOI: 10.1111/epp. 12025

EPPO (2015). EPPO A1 and A2 lists of pests recommended for regulations as quarantine pests. PM 1/2 (24). Paris, France, European and Mediterranean Plant Protection Organization. EPPO Standards.

Fenwick, D. (1940). Methods for the recovery and counting of cysts of Heterodera schachtii from soil. Journal of Helminthology 18, 155-172. DOI: 10.1017/ S0022149X00031485.

Grenier, E., Fournet, S., Petit, E. \& Anthoine, G. (2010). A cyst nematode 'species factory' called the Andes. Nematology 12, 163-169. DOI: 10.1163/138855409X12573393054942

Macara, A. (1963). Aspectos sobre a importância dos nemátodos de interesse agrícola em Portugal e no ultramar português. Agros 46, 367-384.

Marks, B. \& Brodie, B. (1998). Potato cyst nematodes: biology, distribution and control. Wallingford, UK, CAB International.

Santos, S. \& Fernandes, M. (1988). The occurrence of Globodera rostochiensis and G. pallida in Portugal. Nematologia Mediterranea 16, 145.

Seesao, Y., Gay, M., Merlin, S., Viscogliosi, E., Aliouat-Denis, C. \& Audebet, C. (2016). A review of methods for nematode identification. Journal of Microbiological Methods 138, 3749. DOI: 10.1016/j.mimet.2016.05.030

Tirchi, N., Troccoli, A., Fanelli, E., Mokabli, A., Mouhouche, F. \& De Luca, F. (2016). Morphological and molecular identification of potato and cereal cyst nematode isolates from Algeria and their phylogenetic relationships with other populations from distant their geographical areas. European Journal of Plant Pathology 146, 861-880. DOI: 10.1007/ s10658-016-0965-z

Van de Vossenberg, B., Voogd, J., Westenberg, M. \& Karssen, G. (2014). Comparison of three conventional PCR test (Bulman \& Marshall, 1997) versions for the molecular identification of Globodera pallida and G. rostochiensis cysts and juveniles. EPPO Bulletin 44, 27-33. DOI: 10.1111/epp.12101

Varypatakis, K., Blok, V., Cock, P. \& Jones, J. (2016). Identification of avirulence genes in Globodera pallida as tools for assessing durability of resistance. 32nd ESN Symposium Abstract Book, p. 365. [Abstr.] 